\title{
Analisis Putusan Permanent Court of Arbitration Terhadap Klaim Nine Dash Line: Studi Kasus Klaim Wilayah Natuna Utara
}

\author{
Febriyansyah Rahmat Maulana*;Rahayu Repindowaty \\ Fakultas Hukum, Universitas Jambi \\ *Coresponding author: febrimaulana83@gmail.com \\ Submission : 14 September 2020 \\ Revision : 04 November 2020 \\ Publication : 20 November 2020 \\ DOI $\quad$ : doi.org/10.36565/up.v1i2.10452
}

\begin{abstract}
The purpose of this research is to analyze the judgment of Permanent Court of Arbitration on China's Nine Dash Line claim and Indonesia's best strategies to resolve the claim of territory in Natuna Sea. In this study, qualitive methods are used by taking various data and the source of the data to be verified. Chinese claim of "Nine Dash Line" in the Natuna Islands which overlaps with the Indonesian Exclusive Economic Zone (EEZ). This China's claim of "Nine Dash Line" has been protracted for several years and is a serious problem in the region of South China Sea. The ruling of Permanent Court of Arbitration says that China's claim of "Nine Dash Line" are refutable and have no legal basis. But, china is rejects the ruling and still aggressive in the South Chine Sea which has potential to make instability in the region of South China Sea. The result of this study will show that the disputing state parties must implement and respect the ruling because it has became a source of international law. The ruling also has influence in dealing with chinese aggressiveness and regulation of maritime's claim in the region of South China Sea.
\end{abstract}

Keyword:Nine Dash Line; North Natuna; Permanent Court of Arbitration 


\begin{abstract}
Abstrak
Tujuan penelitian ini adalah menganalisis putusan Permanent Court of Arbitrationmengenai klaim "Nine Dash Line" milik Tiongkok dan strategi terbaik Indonesia dalam mengatasi pengklaiman wilayah di perairan Natuna. Dalam penelitian ini menerapkan metode kualitatif dalam menggunakan berbagai data dan sumber yang akan diverifikasi. Klaim Tiongkok tentang "Nine Dash Line" di wilayah Kepulauan Natuna yang tumpang tindih dengan wilayah Zona Ekonomi Eksklusif (ZEE) Indonesia. Klaim “Nine Dash Line” Tiongkok ini telah lama berlarut-larut selama beberapa tahun belakangan dan menjadi permasalahan serius di kawasan Laut China Selatan. Putusan Permanent Court of Arbitration mengungkapkan bahwa klaim Tiongkok mengenai “Nine Dash Line"terbantahkan dan tidak dapat menjadi dasar hukum. Akan tetapi Tiongkok menolak putusan tersebut dan tetap agresif di Laut Cina Selatan yang dapat menimbulkan polemik di kawasan Laut Cina Selatan. Hasil penelitian akan menjelaskan bahwa negara pihak yang bersengketa harus melaksanakan dan menghormati putusan Permanent Court of Arbitration tersebut karena sudah menjadi sumber hukum internasional. Putusan tersebut juga memiliki pengaruh di dalam menghadapi agresivitas Tiongkok dan pengaturan mengenai klaim maritim di kawasan Laut China Selatan.
\end{abstract}

Kata Kunci: Natuna Utara;Nine Dash Line; Permanent Court of Arbitration

\title{
A. Pendahuluan
}

Hukum internasional merupakan sebuah kebiasaan yang menjadi salah satu dasar hukum dimuat dalam Piagam Mahkamah Internasional Permanen Pasal 38 ayat (1).Pasal 38 ayat (1) sub b Piagam Mahkamah Internasional Permanen menyebutkan bahwa international custom, as evidence of a general practice accepted as law. Di definisikan, hukum kebiasaan internasional merupakan kebiasaan umum yang dianggap sebagai hukum. ${ }^{1}$

${ }^{1}$ Lihat Pasal 38 ayat (1) sub b Piagam Mahkamah Internasional Permanen. 
Segala persoalan tentang kemaritiman telah mendapatkan pengkodifikasian hukum final tentang keberhasilan dalam merumuskan hak negara pantai atas kepemilikan laut sejauh 12 mil, dan memiliki zona tambahan sejauh 24 mil serta diaturnya pula atas Zona Ekonomi Eksklusif (ZEE) sejauh 200 mil ditarik dari garis pantai, kemudian dikenal dengan pengaturan mengenai penggunaan laut bebas dan juga penyelesaian sengketa di laut.

Aturan mengenai Zona Ekonomi Eksklusif ini dituangkan dalam BAB V Konvensi Hukum Laut 1982 memiliki 21 Pasal mulai dari pasal 55 sampai dengan 75 , menjelaskan ruang fisik, status hukum termasuk hak dan kewajiban negara pantai. Perairan pada Zona Ekonomi Ekslusif sesungguhnya berstatus laut lepas, hanya saja pada wilayah tersebut berlakunya hak berdaulatnya negara untuk kegiatan mengeksplorasi kekayaan dan mengelola kekayaan Sumber Daya Alam (SDA) yang ada di laut tersebut.

Hadirnya Konvensi Hukum Laut PBB 1982 yang dikenal sebagai UNCLOS 1982 melahirkan berbagai ketentuan yang mewarnai hukum laut internasional. Selanjutnya, Indonesia sebagai bagian dari masyarakat internasional yang ikut bergabung dalam Konvensi Hukum Laut PBB 1982 atau UNCLOS 1982harus mengikuti aturan-aturan atau kaidahkaidah yang ada di dalam konvensi tersebut.

Keikutsertaan Indonesiapada Konvensi Hukum Laut PBB 1982 sejatinya untuk memperoleh manfaat yang maksimal bagi kepentingan nasional perihal wilayah perairan Indonesia.Penyelesaian masalah sengketa perbatasan laut di dalam perkembangan hukum laut internasional modern dikembalikan kepada persetujuanantara negara yang sedang konflik, tetapi harus sesuai dengan ketentuan dalam Hukum Laut PBB 1982.

Akhir-akhir ini, Laut Cina Selatan mengalami banyak persoalan sengketa yang bersumber pada latar belakang 
historis, mulai dari sisi pemberian nama terhadap lautan itu, maupun wilayah dan batas kepemilikannya. ${ }^{2}$ Selain darurat, timbulnya berbagai isu menarik terkait perairan Laut Cina Selatan yang sampai saat ini merupakan salah satu daerah yang paling tidak stabil, dengan munculnya sengketa perairan yang tumpang tindih di daerah itu menciptakan suasana panas berlangsung lama.

ZEE bagilndonesia merupakan hal yang penting hal ini disebabkan karena didalamnya memilikiSumber Daya Alam (SDA) hayati dan non-hayati yang melimpah, kekayaan alam yang melimpah memainkan fungsi yang sangat penting bagi pembangunan ekonomi negara.Hak dan Kewajiban Indonesiaadalah hak-hak, yurisdiksi, dan kewajiban dalam Konvensi Hukum Laut 1982 dengan ratifikasi UU No. 17 Tahun 1985. Hak-hak, yurisdiksi, dan kewajiban Indonesia pada Konvensi tersebut sudah ditentukan oleh Pasal 56UNCLOS. ${ }^{3}$ Dalam proses ratifikasi mementingkan bagaimana negara dapat menerjemahkan isi kesepakatan tersebut kedalam hukum nasional karena mengikuti perubahan ketentuan yang berlaku dalam sebuah negara. ${ }^{4}$

Secara spesifik tentang Zona Ekonomi Eksklusif,hak dan kewajiban Negara Indonesia berdasarkan Konvensi Hukum

${ }^{2}$ Hervian Putra Dharma.Indonesia's Military and Diplomatic Responses to People Republic of China's Assertiveness In The Natuna Islands. Tesis Magister Hubungan Internasional. Jakarta: President University. 2017. hal. 1.

${ }^{3}$ Ibid.

${ }^{4}$ Hikmahanto Juwana. Kewajiban Negara dalam Proses Ratifikasi Perjanjian Internasional: Memastikan Keselarasan dengan Konstitusi dan Mentransformasikan ke Hukum Nasional. Undang: Jurnal Hukum, 2(1), hal. 4. 
Laut 1982 (UNCLOS) ${ }^{5}$ setelah meratifikasi melalui UU No. 17 Tahun 1985 dapat dijabarkan berikut ini :6

1. Pasal 55-75 tentang ZonaEkonomi Eksklusif sejauh 200 mil memberikan hak dan kewajiban Indonesia:

a. Hak-hak Indonesia yakni hak berdaulat dan Yurisdiksi negara, bukan berada dalam kedaulatan Indonesia.

b. Kewajiban Indonesia adalah Dapat memberikan hak pakai pada negara lain untuk mengolah dan memanfaatkansumber daya hayati, Wajib melakukan konservasiatas sumber daya hayati dan non-hayati, Penegakkan hukum atas tindakan pelanggaran di ZEE Indonesia, Tindakan hukum yang diambil karena banyak kapal asing berorasi dan mengambil keuntungan, Penyelesaian batasbatas ZEE Indonesia dengan negara lain, dan Wajib membuat peta dan koordinat geografis dan menyampaikan Salinannya ke Sekjen PBB.

Apabila ditemukannya permasalahan dikemudian hari, Indonesia juga memiliki hak dan kewajibannya sebagai berikut

2. Pasal 279-299: Penyelesaian sengketa bidang hukum laut: ITLOS, ICJ, Arbitrase,dan Arbitrase Khusus.

a. Hak-hak Indonesia, yakni setiap negara mempunyai hak untuk menyelesaikan sengketa bidang hukum laut secara bilateral dan keempat forum tersebut.

b. Kewajiban Indonesia adalah Setiapnegara anggota berkewajiban menyelesaikansengketa di bidang hukum laut secara damai dari mulai

${ }^{5}$ United Nations Convention on the Law of the Sea 1982.

"Peni Susetyorini."Kebijakan Kelautan Indonesia Dalam Perspektif UNCLOS 1982". Jurnal Ilmu Hukum Universitas Diponegoro.Masalah-Masalah Hukum Jilid 48 No.2. April 2019.hal. 169. 
negosiasisampai ICJ.7Indonesia harus berusaha keras dalam menjaga dan melaksanakan kedaulatan dan yuridiksi negara atas berbagai kekayaan laut.

Pada tahun 1947, Tiongkok8telah mengklaim wilayah Laut Cina Selatan dengan menerapkan klaim sembilan garis putus-putus yang disebut dengan "nine dashline" kemudian dicantumkan dalam peta yang diterbitkan olehDepartemen Geografi Kementerian Dalam Negeri Republik Rakyat Tiongkok. ${ }^{9}$

Klaim sepihak yang dilakukan oleh Tiongkok menuai banyak kecaman darimasyarakat internasional, khususnya dari beberapa negara yang berbatasan langsung dengan Laut Cina Selatan. konflik klaim wilayah laut telah diatur secara jelas dalam UNCLOS pada tahun 1982 atau yang disebut dengan Konvensi Hukum Laut PBB 1982. Bahwa setiap negara pantaiatau coastal stateberhak untuk melakukan klaim terhadap wilayah laut teritorial sejauh 12 mil laut, 24 mil laut zona tambahan, 200 mil laut Zona Ekonomi Eksklusifatau tidak boleh lebih dari 350 mil laut wilayah landas kontinen. ${ }^{10}$

7 Statute of International Court of Justice.

8 Penyebutan Tiongkok berdasarkan Keputusan Presiden Nomor 12 Tahun 2014 tentang Pencabutan Surat Edaran Presidium Kabinet Ampera Nomor SE06/PRES.KAB/6/1967. penyebutan istilah Tiongkokmerujukkepada penyebutan negara saja. Tetapi penyebutan terhadap istilah Laut China Selatan tidak diubah menjadi Laut Tiongkok Selatan karena Keputusan Presiden tersebut hanya menetapkan pengubahan terhadap istilah orang dan atau komunitas, dan penyebutan negara.

${ }^{9}$ Ana Fatmawati dan Elsa Aprina. Keabsahan Alasan Penolakan Republik Rakyat Tiongkok Terhadap Putusan Permanent Court Arbitration Atas Sengketa Klaim Wilayah Laut Cina Selatan Antara Filipina dan Republik Rakyat Tiongkok Berdasarkan Hukum Internasional. Jurnal Ilmu Hukum Universitas Balikpapan, VeJ Volume 5, Nomor 1.hal. 106. 
Tiongkoksebagai negara yang turut serta dalam Konvensi Hukum LautPBB 1982 seharusnya memahami dan mengetahui bahwa pada wilayah Zona Ekonomi Ekslusif suatu negara itu sejauh 200 mil yang ditarik dari garis pantai sesuai dengan Pasal 57 Konvensi Hukum Laut PBB 1982. Namun nyatanya Tiongkok menggunakan pula klaim berlandaskan sejarah leluhurnya terdahulu sejak tahun 1947 pada Kerajaan Koumintang yang disebut nine dash line.

Paham historic righttentang nine dash line,yang menurut

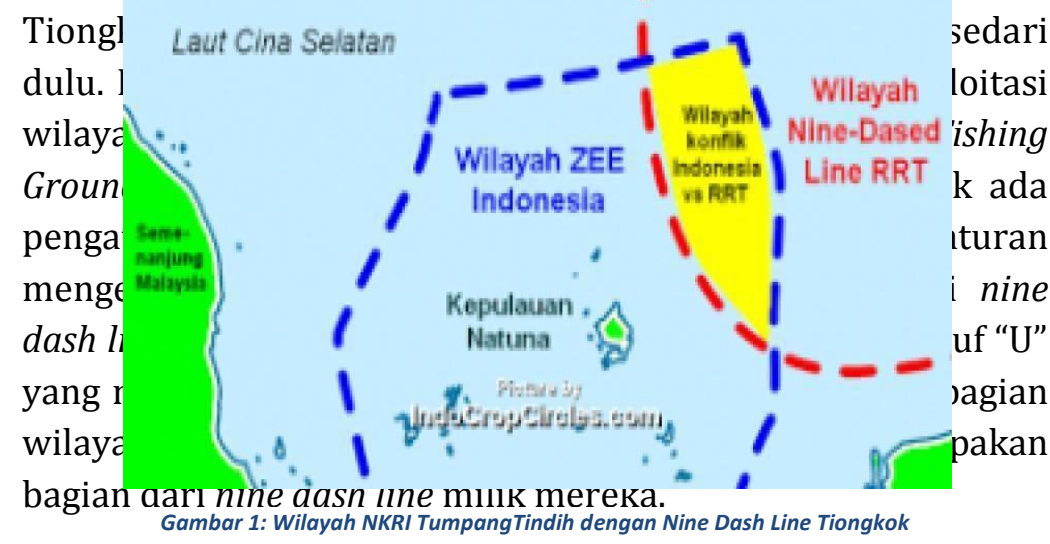

Jika dilihat dari gambar di atas, wilayah perairan Natuna Indonesia tumpang tindih dengan klaim tiongkok nine dash line. yang menjadi permasalahan, Permanent Court of 
Arbitration telah mengeluarkan putusan yang menyatakan bahwa nine dash line itu tidak memiliki dasar hukum yang jelas dan menolak hak sejarah dari Tiongkok di Laut Cina Selatan. Seharusnya putusan tersebut dapat dijadikan pedoman penyelesaian permasalahan atas klaim Tiongkok dalam sebagian wilayah laut Indonesia.

Berdasarkan latar belakang masalah yang telah diuraikan sebelumnya bahwa didalam Pasal 57Konvensi Hukum Laut PBB 1982 menyatakan bahwa Negara memiliki wilayah hak berdaulatnya secara eksklusif atas kegiatan perekonomian di Zona Ekonomi Ekslusif sejauh 200 mil laut yang ditarik dari garis pantai negara masing-masing, sementara Tiongkok mengklaim wilayah Laut Cina Selatan 90 \% nya merupakan bagian dari wilayah eksklusif mereka yang diberi nama nine dash line.

Selanjutnya permasalahan mengerucut pada tumpang tindihnya wilayah di Perairan Natuna yang mengakibatkan pelanggaran lain pun dilakukan oleh Kapal Nelayan Tiongkok yang di kawal oleh CCG (Chinese Coast Guard) untuk mengambil ikan di Natuna tanpa seizin Pemerintah Indonesia. Melihat tindakan ini, Tiongkok sama sekali tidak menghormati kedaulatan Indonesia.

\section{B. Metode Penelitian}

Jenis penelitian ini merupakan penelitian hukum normatif, penelitian hukum tersebut dilakukan untuk memberikan argumentasi,teori, ataukonsep barudalam memecahkan permasalahan yang dihadapi. Penelitian hukum ini adalah jenis penelitian hukum yang didapat dari studi kepustakaan, yang menganalisis suatu masalah hukum 
melalui beberapa peraturan perundang-undangan, literaturliteratur dan bahan-bahan referensi lainnya. ${ }^{11}$

\section{Pembahasan}

1. Kekuatan Hukum Putusan Permanent Court of Arbitration atas Klaim "Nine Dash Line" oleh Tiongkok

Pasal 55 UNCLOS (United Nations Convention on the Law of the Sea) 1982mendefinisikan Zona Ekonomi Ekslusif selaku perairan (laut) yang terletak di luar serta berbatasan dengan laut teritorial, tunduk pada rezim hukum khusus. Status Natuna telah terperinci dijelaskan bahwa merupakan bagiansahdari NKRI yang wilayahnya termasuk dalam 12 mil laut teritorial Indonesia kemudian didukung dengan Konvensi Hukum Laut Internasional 1982.

Berkembangnya persoalan Laut Cina Selatan berhubungan dengan berbagai masalah yang sangat penting dan mendesak yaitu berhubungan dengan kedaulatan teritorial Indonesia yang berada di wilayah Natuna yang seolah membahayakan. Klaim Tiongkok di wilayah perairan Kepulauan Natuna didasarkan pada klaimhistorismemasukkan sebagian wilayah perairan tersebut menjadi wilayah kepemilikan Tiongkok dan memperbolehkan warga negaranya untuk melakukan aktivitas di atas perairan tersebut, adanya sejarah leluhur yang mengatakan pelaut Tiongkok dimana konon di lokasi tersebut merupakan bagian dari perairan tradisional Tiongkok.

wilayah Zona Ekonomi Eksklusif yang secara langsung hanya dimiliki oleh negara bersangkutan terbatas sepanjang menyangkut masalah ekonomi dan bagi negaranegara asing yang berkeinginan memanfaatkan wilayah tersebut harus mendapatkan izin dari pemerintah sebagai

11 Peter Mahmud Marzuki. Penelitian Hukum, Cet. 8 Edisi Revisi. Kencana Prenada Media Group. Jakarta. 2013, hal. 52. 
pemilik wilayah tersebut, sedangkan untuk kepentingan lainnya di luar itu dapat dilakukan dengan segala tujuan damai. ${ }^{12} \mathrm{Hal}$ ini tercantum dalam Undang Undang Republik Indonesia No. 5 Tahun 1983.

Ketentuan-ketentuan hukum mengenai Zona Ekonomi Eksklusif diatur dalam Undang-Undang No. 5 Tahun 1983 Pasal 5 Ayat (1) yang berbunyi:

"Dengan tidak mengurangi ketentuan Pasal 4 ayat (2), barang siapa melakukan eksplorasi dan/atau eksploitasi sumber daya alam atau kegiatan-kegiatan lainnya untuk eksplorasi dan/atau eksploitasi ekonomis seperti pembangkitan tenaga dari air, arus dan angin di Zona Ekonomi Eksklusif Indonesia, harus berdasarkan izin dari Pemerintah Republik Indonesia atau berdasarkan persetujuan internasional dengan Pemerintah Republik Indonesia dan dilaksanakan menurut syarat-syarat perizinan atau persetujuan internasional tersebut."13

Pasal tersebut mengartikan bahwa Negara asing yang memasuki atau ingin mengeksploitasi sumber daya alam dibawah laut wilayah Zona Ekonomi Eksklusif Indonesia harus berdasarkan izin dan memenuhi syarat-syarat dari Indonesia terlebih dahulu.Perairan Natuna adalah wilayah milik Indonesia yang berbatasan dengan Laut Cina Selatan dampak dari kondisi apapun yang berlangsung di Laut Cina Selatan sangat mempengaruhi perekonomian Indonesia terutama terkait dengan Sumber Daya Alamnya (SDA) dan Indonesia menggunakan lintasan Laut Cina Selatan sebagai jalur perdagangan.

Putusan arbitrase Permanent Court of Arbitrationsecara jelas dapat mengikat para pihak bahkan

12 P. Joko Subagyo.Hukum Laut Indonesia. Cet. 5, Rineka Cipta. Jakarta. 2013.hal. 21

13 Ibid., Pasal 5 ayat (1).

Uti Possidetis: Journal of International Law, Vol. 1, No. 2 (2020) 
putusan yang telah disahkan dapat bersifat final, seharusnya telah dapat menjelaskan tindakan sewenang-wenang yang tidak dapat dibenarkan. Bersumber pada putusanatas klaim Nine Dash Lineyang dilakukan Tiongkok sepatutnya Tiongkok melihat ketentuan bukan hanya berdasarkan Historical tetapi merujuk pada ketentuan baik internasional maupun hukum nasional Indonesia.

Tindakan lebih lanjut dengan pengupayakan perdamaian dapat dilakukan dengan mempertimbangkan bentuk dari kerugian yang ditimbulkan Tiongkok selama ini dengan pertanggungjawaban yang harus diberikan atas klaim sepihak tersebut. Walaupun ketegangan selama ini belum pernah menimbulkan akibat yang buruk seperti perang secara terbuka antara kekuatan militer negara yang berkepentingan dari dalam dan luar kawasan, tetapi akhir-akhir ini kegiatan saling unjuk kekuatan dan provokasi semakin rawan sewaktuwaktu mengarah pada perang terbuka. ${ }^{14}$

\section{Bentuk Penanganan yang Tepat untuk Menyelesaikan Konflik yang Terjadi antara Indonesia dan Tiongkok Mengenai Wilayah Zona Ekonomi Eksklusif Indonesia pada Konflik Klaim Sepihak yang dilakukan oleh Pemerintah Tiongkok}

Beberapa masalah yang terjadi di laut muncul karena adanya berbagai pihak yang ingin mengambil keuntunganfasilitas laut. Tumbuh berkembangnya Hukum Laut atau UNCLOS 1982 selain karena adanya kepentingan dengan alasan milik bersama, juga perlu dijaga : ${ }^{15}$

14 Rizki Roza, Poltak Partogi Nainggolan, Simela Victor Muhamad.Konflik Laut China Selatan dan Implikasinya Terhadap Kawasan.Pusat Pengkajian Pengolahan Data dan Informasi.Setjen DPR Republik Indonesia dan Azza Grafika. Jakarta. 2013.hal. 11.

P. Joko Subagyo.Op. Cit., hal. 35. 
1. Kepentingan yang berhubungan dengan keamanan dan stabilitas negara;

2. Terbatasnya sumber daya;

3. Pembagian kepentingan;

4. Menjaga dan menuju pelestarian lingkungan laut dengan segala ekosistemnya.

Walaupun Indonesia bukan merupakan anggota dari klaim Nine Dash Line, Indonesia tetap berhak untuk menjaga kedaulatan wilayah serta sumber daya alam demi kelangsungan masyarakat. Negara Indonesiadalam menghadapi sepihak klaim yang dilakukan Tiongkok harus bersifat objektif dan subjektif dengan memasukkan kepentingan nasional yakni ekonomi dan kedaulatan. ${ }^{16}$

Laut Cina Selatan bukan merupakan milik Tiongkok atau negara manapun, tetapidapat disebut dengan no man's island, namun laut ini memang biasa digunakanuntuk jalurperdagangan antar negara. ${ }^{17}$ Pemerintah Indonesia dapat melakukan upaya deterrence atau menangkal dengan mengancam Tiongkok dengan tegas untuk melakukan penangkapan dan eksekusi terhadap kapal asing yang masuk secara illegal ke perairan Natuna sesuai dengan ketetapan Undang-Undang Nomor 5 Tahun 1983. Adanya tuntutan hukum tentang Zona Ekonomi Eksklusif (ZEE) yaitu Undang Undang No.5 tahun 1983. Undang-undang ini berisi mengenai perbatasan Indonesia yang terdiri dari dasar laut, tanah di dalam lautan dan dengan batasan terluar sebesar 200 mil dari garis pangkal laut wilayah kedaulatan Indonesia. Ketentuan

16 Kementrian Luar Negeri Republik Indonesia, Pertemuan Kelompok Ahli (PKA) "Perkembangan Di Laut China Selatan Dan Dampaknya Bagi Satbilitas Politik Dan Keamanan Di Kawasan Asia Pasifik : Penguatan Posisi dan Strategi RI" dalam http://kemlu.go.id diakses pada tanggal 4 Agustus 2020, Pukul 22.19 WIB.

17 http://www.jpf.or.id/id/jepang-indonesia-dan-konflik-laut-cinaselatan, diakses pada tanggal 4 Agustus 2020, Pukul 23.32 WIB.

Uti Possidetis: Journal of International Law, Vol. 1, No. 2 (2020) 
hukum ini merupakan janji Indonesia untuk mempertahankan Indonesia dari nine dash line klaim Tiongkok. Nine dash line sendiri bertentangan dengan Hukum Internasional yaitu UNCLOS1982.

Langkah ini sebagai upaya yang jelas. dalam menghadapi klaim sepihak dengan peraturan yang ada dan bukan sebagai alasan Historical Indonesia dalam menghadapi Tiongkok. Pihak Tiongkok sekiranya harus dan perlu memahami akibat yang ditimbulkan atas permasalahan dengan beberapa metode, salah satunya mengelola sumber daya yang baik dan tersusun dari berbagai kegiatan kapal nelayan Tiongkok di wilayah tersebut sebagai salah satu kunci untuk melanjutkan kembali perundingan antara Indonesia dan Tiongkok.

Jokowi berfokus mengubah nama Perairan Natuna untuk mengurangi nelayan ilegal dan penjaga laut dari Tiongkok maupun dari negara lainnya. Dengan mengadakan perjanjian bilateral antara Indonesia dan Tiongkok tentang kepemilikan perairan Natuna yang tumpang tindih dengan klaim nine dash line milik Tiongkok. Negara berkepulauan wajib menentukan garis-garis dasar pangkal kepulauan dengan skala yang dapat menggambarkan posisinya, dan salinannya dikirimkan pada Sekretaris Jenderal Perserikatan Bangsa-Bangsa.

Penulis disini memilih langkah penanganan secara damai, penyelesaian sengketa secara damai memiliki 7 prinsip yaitu :

1. Prinsip Itikad Baik (Good Faith);

2. Prinsip Larangan Penggunaan Kekerasan dalam Penyelesaian Sengketa;

3. Prinsip Kebebasan Memilih Cara-Cara Penyelesaian Sengketa;

4. Prinsip Kebebasan dalam Memilih Hukum yang akan Diterapkan terhadap Pokok Sengketa;

5. Prinsip Kesepakatan antara Para Pihak yang Bersengketa;

6. Prinsip Exhaustion of Local Remedies; 
7. Prinsip-Prinsip Hukum Internasional tentang Kedaulatan, Kemerdekaan, dan Integritas Wilayah Negara-Negara.

Upaya negosiasi didefinisikan sebagai upaya penyelesaian konflik yang paling umum dan yang paling lama telah dipakai manusia. Negosiasi dapatdikatakan sebagai kegiatan yang paling penting. Terdapat banyak pokok permasalahan yang diselesaikan setiap hari melalui upaya ini tanpa adanya publisitas atau perhatian publik ${ }^{18}$ dan secara langsung dapat diterapkan dalam permasalahan ini.

Alasan paling mendasar adalah dengan cara ini, para pihak dapat mengawasi jalannya prosedur penyelesaian sengketadan setiap upaya berdasarkan kesepakatan atau konsensus para pihak.

Namun adapun kelemahan utama pengguna cara ini dalam menyelesaikan perkara adalah :

1. Posisi para pihak tidak seimbang, salah satu pihak memiliki kekuatan, sedangkan pihak yang lain lemah. Pihak yang kuat berada dalam posisi yang memungkinkan dirinya untuk menekan pihak lain. Hal ini acap kali terjadi manakala dua pihak bernegosiasi untuk menyelesaikan perkara di antara mereka; ${ }^{19}$

2. Proses terjadinya negosiasi sering kali lambat memakan waktu lama. Terutama dikarenakan permasalahan antarnegara yang muncul, khususnya masalah yang berkaitan dengan ekonomi internasional lainnya;

3. Apabila suatu pihak terlalu keras dengan pendiriannya . keadaan ini dapat mengakibatkan proses negosiasi menjadi tidak produktif.

18 Huala Adolf.Hukum Penyelesaian Sengketa Internasional. Sinar Grafika. Cet. 4, 2012. Jakarta. hal. 19.

Ibid. 
Bilamana cara ini berhasil, hasilnya biasanya dituangkan dalam sebuah yang memiliki kekuatan hukum. Misalnya hasil kesepakatan negosiasi yang dituangkan dalam bentuk suatu dokumen perjanjian perdamaian. ${ }^{20}$

Cara tersebut dapat memberi landasan hukum berupa perjanjian bilateral atau konvensi, mengikat negara-negara yang mengikatkan diri terhadapnya. Pada akhirnya upaya damai yang dituangkan dalam aturan atau perjanjian internasional adalah untuk menghindari tindakan sewenangwenang atau mencegah penggunaan cara kekerasan, militer atau perang sebagai cara penyelesaian konflik yang ada.

Pemerintah Indonesia juga dapat melibatkan tindakan Tiongkok sebagai tindakan melawan hukum sebagai langkah pertama karena Indonesia telah membuat aturan mengenai Kegiatan di Zona Ekonomi Eksklusif sebagai mana tercantum pada pasal 5 ayat (1) Undang-Undang No. 5 Tahun 1983 tentang Zona Ekonomi Ekslusif yang menjelaskan tindakan pengeksploitasi sumber daya alam tanpa izin Pemerintah Indonesia dan memiliki ketentuan pidanapada BAB VII Pasal 16 ayat (1) Undang-Undang No. 5 Tahun 1983 yang berbunyi :

"Barangsiapa melakukan tindakan-tindakan yang bertentangan dengan ketentuan Pasal 5 ayat (1), Pasal 6, Pasal 7 dipidana dengan denda setinggitingginya $\mathrm{Rp} 225.000 .000$,- (dua ratus dua puluh lima juta rupiah)."21

\section{Penutup}

Berdasarkan pembahasan permasalahan di atas dapat ditarik kesimpulan yaitu:

1. Adanya putusan Permanent Court of Arbitration disini mengenai "Nine dash line" perlu diakui dan ditindaklanjuti

20 Ibid., hal. 27.

21 Lihat Undang-Undang No. 5 Tahun 1983 Tentang Zona Ekonomi Ekslusif Indonesia Pasal 16 ayat (1). 
secara hukum internasional sebagai upaya dalam penyelesaian sengketa, diharapkan putusan ini dapat dihormati oleh seluruh pihak dan dengan adanya putusan tersebut, Tiongkok diharapkan pulamenghormati putusan sebagai bentuk itikad baik dalam konflik Laut Cina Selatan yang terjadi berlarut-larut ini.

2. Upaya yang dilakukan Pemerintah Indonesia adalah dengan cara pengubahan namadapat mempengaruhi geopolitik kawasan dimana nama Laut Natuna Utara menunjukkan hak maritim Indonesia atas wilayah Perairan Natuna. Tujuan Indonesia dalam pengubahan nama ini bukan untuk meningkatkan konflik dengan Tiongkok, namun justru untuk mempertahankan wilayah Perairan Kepulauan Natuna yang merupakan milik Indonesia. Selain pengubahan nama, bentuk penanganan untuk menghadapi Tiongkok adalah dengan melakukan penyelesaian konflik secara damai melalui negosiasi dan membuat perjanjian bilateral antara Pemerintah Indonesia dengan Pemerintah Tiongkok tentang Laut Natuna Utara agar terang dan menemukan jalan keluar dari konflik yang terjadi.

Adapun saran berdasarkan pembahasan permasalahan di atas yaitu:

1. Putusan Permanent Court of Arbitration mengenai nine dash line tidak cukup untuk membuat Tiongkok bungkam. Maka dari itu, Indonesia dalam menjalankan Undang-Undang No. 5 Tahun 1983 haruslah tegas jika tindakan Tiongkok dalam illegal fishing dibiarkan maka bisa saja daerah tersebut diklaim oleh Negara lain terutama Tiongkok.

2. Memperbanyak armada keamanan batas wilayah di perairan natuna.

3. Indonesia harus membuat kesepakatan perjanjian bilateral dengan Tiongkok mengenai Natuna. 
4. Indonesia diharuskan mengadakan perjanjian secara multilateral juga dan membahas Laut Cina Selatan bersama Negara-Negara yang berdampingan dengan wilayah Laut Cina Selatan agar ditemukannya kesepakatan batas wilayah dan beserta titik koordinat nya agar Tiongkok tidak semena-mena atau tidak memiliki upaya untuk mengklaim wilayah Laut Cina Selatan

\section{Referensi}

\section{Buku}

Adolf, Huala. Hukum Penyelesaian Sengketa Internasional.Sinar Grafika. Cet. 4, Jakarta. 2012.

Subagyo, P. Joko. Hukum Laut Indonesia. Cet. 5, Rineka Cipta. Jakarta. 2013.

Marzuki, Peter Mahmud. Penelitian Hukum. Cet. 8 Edisi Revisi. Kencana Prenada Media Group. Jakarta. 2013.

Roza. Rizki, Poltak Parogi Nainggolan, Simela Victor Muhammad.Konflik Laut China Selatan Terhadap Kawasan. Pusat Pengkajian Pengolahan Data dan Informasi. Setjen DPR dan Azza Grafika. Jakarta. 2013.

Soebekti. Pengantar Ilmu Hukum. Cet. 13, PT. RajaGrafindo Persada. Jakarta. 2010.

\section{Jurnal}

Susetyorini, Peni.Kebijakan Kelautan Indonesia Dalam Perspektif UNCLOS 1982.Jurnal Ilmu Hukum Masalah-Masalah Hukum Universitas

Diponegoro,Jilid 48, No.2, April 2019.

Fatmawati, Ana dan Aprina, Elsa. Keabsahan Alasan

Penolakan Republik Rakyat Tiongkok Terhadap 
Putusan Permanent Court Arbitration Atas Sengketa Klaim Wilayah Laut Cina Selatan Antara Filipina dan Republik Rakyat Tiongkok Berdasarkan Hukum Internasional.Jurnal Ilmu Hukum Universitas Balikpapan, VeJ Volume 5, Nomor 1.

\section{Peraturan Perundang-undangan}

Republik Indonesia, Undang-Undang Tentang Zona

Ekonomi Eksklusif Indonesia Nomor 5 Tahun 1983, Lembaran Negara Republik Indonesia Nomor 44 Tahun 1983, Tambahan Lembaran

Negara Republik Indonesia No. 3260.

Republik Indonesia, Undang-Undang Tentang Pengesahan dan Pengundangan Konvensi Hukum Laut 1982 Nomor 17 Tahun 1985, Lembaran Negara Republik Indonesia Nomor 76 Tahun 1985, Tambahan Lembaran Negara Republik Indonesia No. 3319.

Permanent Court of Arbitration

Statute of International Court of Justice.

United Nations Convention on the Law of the Sea 1982.

\section{Karya Ilmiah}

Dharma, Hervian Putra. Indonesia's Military and Diplomatic Respones to People Republic of China's Assertiveness In The Natuna Islands.Tesis Magister Hubungan Internasional President University. Jakarta. 2017.

Juwana, Hikmahanto. Kewajiban Negara dalam Proses Ratifikasi Perjanjian Internasional: Memastikan Keselarasan dengan Konstitusi dan Mentransformasikan ke Hukum Nasional. Undang: Jurnal Hukum, 2(1), hal. 4. 
Pradana, Adhi.Pelanggaran Zona Ekonomi Eksklusif Di Perairan Natuna Dalam Perspektif Hukum Laut Internasional. Skripsi Fakultas HukumUniversitas Sumatra Utara. Medan. 2017. Purwanti, Evi. Equitable Principle dalam Penentuan Delimitasi Perbatasan Indonesia dengan NegaraNegara Lain di Zona Ekonomi Eksklusif dan Landasan Kontinten. Disertasi. Universitas Gadjah Mada. Yogyakarta. 2016.

\section{Website}

http://kemlu.go.id

http://www.jpf.or.id/id/jepang-indonesia-dan-konfliklaut-cina-selatan 